\title{
Is Nigerian Economy Anti-Philip`S Curved? An Implication for Sustainable Development
}

\author{
Abalaba Bamidele Pereowei \\ Ogunleye Akin George, PhD \\ Osun State University, Osogbo, Nigeria \\ Omitogun Olawunmi, PhD \\ Aderemi Timothy Ayomitunde \\ Olabisi Onabanjo University, Nigeria
}

Doi: 10.19044/elp.v7no2a1 URL:http://dx.doi.org/10.19044/elp.v7no2a1

\begin{abstract}
This study examined the relationship between unemployment and inflation between 1990 and 2018 with a view to testing the existence or otherwise of Philip`s curve theory in Nigeria. The objective of this study was addressed via the application of Engle and Granger and Error Correction Model approach. The following are the major findings that originated from this work; the speed of adjustment for inflation and unemployment to return to the long run equilibrium state when there is a short run disequilibrium due to shock is $16 \%$ on annual basis. The lagged value of unemployment rate is positive in both the short run and the long run. In the same vein, the short run estimate shows a positive relationship between unemployment and inflation in Nigeria, though not statistically significant. This implies that the Nigerian economy is anti-Philip's curved in the short run. However, the long run relationship between the variables of interest shows the evidence to support the existence of Philip's Curve theory in Nigeria. Therefore, this study makes these policy recommendations to the policy makers in Nigeria based on its findings: since both inflation and unemployment are macroeconomic problems that could hinder the achievement of sustainable development goal 8- inclusive and sustainable economic growth, full and productive employment and decent work for all, the policy makers in Nigeria should embark on various stabilization policies to address continuous rising in inflation rate and create jobs to address unemployment menace in the country.
\end{abstract}

Keywords: Inflation: Unemployment: Philip's Curve theory; Nigeria. JEL Classification: E24, E31, P24. 


\section{Introduction}

The stability of macroeconomic variables has always been the strategic goals of the policy makers in any economy. Meanwhile, in achieving a sustainable economic growth, the economy must be operating at full employment and single digit inflation rate. Evidence from advance economies have shown that full employment and single digit inflation rate could co-exist,

However, in developing economies of Africa, especially Nigeria inflation and employment are critical issues because despite the fact that country like Nigeria possesses high level of inflation rate, yet rising unemployment has been the order of the date in the country (Olubaduwe, 2009). It has been argued in the literature that a single-digit inflation rate alongside about five percent unemployment rate has the capacity to guarantee macroeconomic stability in an economy holding other factors constant. Sustainable development requires stable macroeconomic variables such as economic growth, inflation rate, employment rate, exchange rate etc. It is instructive to state that perpetual instability of these variables makes developmental planning difficult in the economy.

In Nigeria, inflation and unemployment remain issues of concern among the policy makers and academia in the recent times, because a cursory look into the Nigerian economy shows that there is a continuous non reverse upward movement in the prices of many essential commodities alongside increasing armed of unemployed youth searching for jobs on daily basis without hope of getting one. This implies that continuous rising in prices coexists with unemployment which contradicts the proposition of Philips curve theory which stipulates the existence of a tradeoff between inflation and unemployment in an economy.

Meanwhile, an attempt to empirically investigate the nexus between inflation and unemployment in Nigeria has generated divided opinions in the past studies. For instance, Aminu \& Anono (2012), Fagge (2011) submitted that unemployment and inflation have an inverse relationship in the country. However, Salisu, Chindo, Yahaya and Bello (2018) and Anthony, Anthony and Joan (2015) reported a direct relationship between unemployment and inflation in the country. Therefore, the conflicting results identified in the literature could spell doom for policy making in particular and general welfare of the society at large. In order to bridge this gap, there is a need for urgent reexamination of this subject matter in this study. Against this backdrop, this study examines the nexus between unemployment and inflation in Nigeria.

In addition to the introductory aspect of this study, the rest of the work is organized as follows; section two presents review of literature while section three presents methodology, discussion of results and policy recommendation. 


\section{Objective of the Study}

The objective of this study is to examine the relationship between unemployment and inflation between 1990 and 2018 with a view to testing the existence or otherwise of Philip`s curve theory in Nigeria.

\section{Literature Review Philip's Curve}

In attempting to provide an answer to one of the basic questions in macroeconomic theory vis-à-vis the cause of inflation, a British economist, A.W. Phillips published his work which utilized data from the U.K. labour market in 1958. Philips aimed to find empirical argument to substantiate the Keynesian proposition which states that the rate of increase in nominal (money) wage rates was a function of the labour market tightness. The level of unemployment was a reflection of the tightness of the labour market in the United Kingdom. As such, Phillips wanted to verify if there exists a statistical evidence that corroborates the hypothesis that the level of unemployment and the rate of change of unemployment could explain the rate of change of money wage rates in the United Kingdom at that time.

However, Phillips's theory is very straight forward because it operates on the labour market principle such that, if for some reason the demand for labour goes up relative to its supply then it is expected that equilibrium wage rates rise above current wage levels. This would lead to upward pressure on nominal wages as a result firms bidding for additional workers. Hiring additional workers would cause fall in unemployment rate. It is important to state that the determinant of the upward or downward pressure on wage rates is the level of the discrepancy between the quantity of labour demanded and the quantity supplied in the market. Therefore, excess supply of labour would give birth to a rising unemployment.

Figure 1: Hypothetical Phillip's Curve.

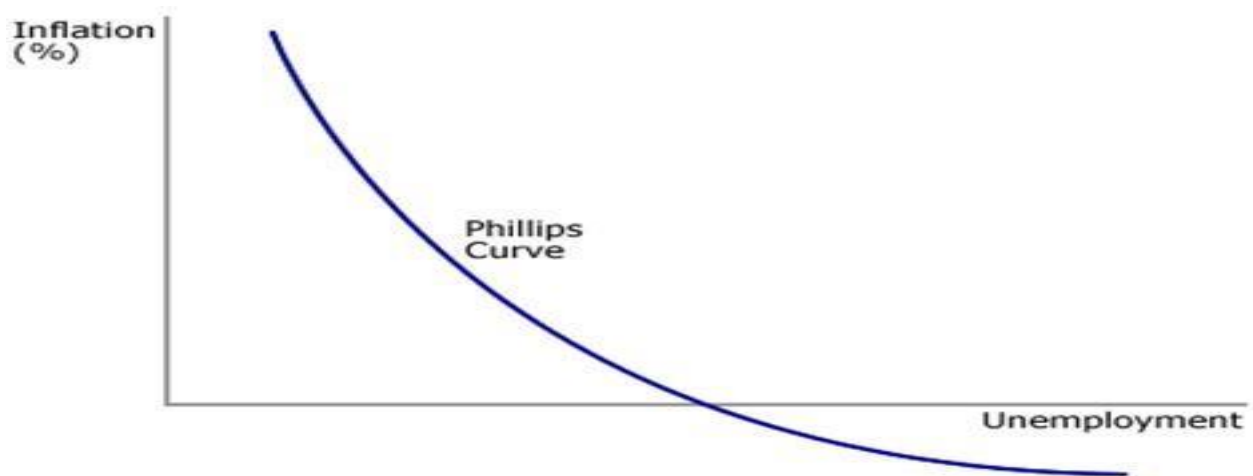


Consequently, Phillips discovered from 1861 to 1957 historical data that the rate at which nominal wage was growing had an inverse correlation with unemployment rate, i.e. low unemployment rates associated with rapidly rising wages whereas high unemployment rates were associated with slowly rising wages. In the same vein, Phillips asserted that the strength of the unemployment vis-à-vis wage-change nexus seemed to be a function of unemployment level. At low unemployment level, decline in unemployment associated with big rise in wage inflation meanwhile, reverse was the case when unemployment was high because, fall in the unemployment rate seemed to orchestrate small increases in wage growth rates.

\section{Empirical Review}

Studies focusing on theoretical and empirical relationships between inflation and unemployment have been pronounced in the recent times. This section of the study presents the perceptions of various scholars regarding this subject matter. For instance.

Anthony, Anthony and Joan (2015) examined the nexus between inflation and unemployment in Nigeria with a view to testing the possibility of original Phillips curve proposition holding in the country between 1970 and 2011. The authors adopted a distributed lag model to submit that the significant determinant of unemployment is inflation in one hand and a direct relationship between inflation and unemployment rate existed in Nigeria. This implies that the original submission of the Phillips curve hypothesis could not hold in Nigeria. In another related study, Fagge (2011) utilized a Johansen technique to investigate the link between unemployment and inflation in Nigeria from 1965 to 2009. It was discovered from the study that an inverse relationship existed between unemployment and inflation in the long run in the country.

Meanwhile, Salisu, Chindo, Yahaya and Bello (2018) assessed the applicability of Philips' curve theory with the reference to inflation and unemployment historical data between 1961 and 2015 in Nigeria. The study employed ARDL-bound testing approach for its both long run short run analysis. The findings from the study posited that a long-run relationship between inflation and unemployment existed in Nigeria. Similarly, an insignificant direct relationship existed between inflation and unemployment in the country. This means that no significant impact of inflation was felt on unemployment in the country. Hence, the Philips curve theory is contradicted in Nigeria. In another perspective, Aminu \& Anono (2012) used Ordinary Least Square and Granger causality approach to estimate the nexus between inflation and unemployment in Nigeria from 1975 to 2009. It was discovered from the study that an inverse relationship existed between unemployment and 
inflation in Nigeria. The results of Causality test showed that no feedback effect existed between unemployment and inflation in the country.

However, Ola- David and Oluwatobi (2012) subjected the Nigerian unemployment and output data to empirical investigation in order to find evidence or otherwise of an Okun-type relationship in Nigeria between 1970 and 2009. The study argued that a negative relationship exists between unemployment and output in the long run in Nigeria. In an explicit format, the Okun coefficient was discovered to be $1.75 \%$. This shows that a unit change in unemployment rate brings about $1.75 \%$ rise in output in the country. Carlos (2010) utilized Bayesian econometric technique to appraise the relevance or otherwise of the Phillips curve tool in conducting monetary policy in African countries with a case study of Nigeria, wishing to adopt an inflation targeting regime. The researcher opined the inflation rate could be regulated via Phillips curve vis-à-vis the sterilization of the resources from oil exports and a Taylor rule that includes the exchange rate by the Central Bank of Nigeria.

Furthermore, while examining the linkage between inflation and unemployment in a cross country analysis of the United States and the United Kingdom, Tejvan (2011) submitted that there was an existence of some tradeoff between unemployment and inflation in both the economies. As inflation was rising, unemployment rate was declining during the period under study in the both countries. In the same vein, Dritsaki and Dritsaki (2012) verified evidence to support Philips curve hypothesis in Greece. The authors discovered the existence of a long run convergence between unemployment and inflation in the country. In another related study in the United States, Alfred and Ian (2011) investigated the long run linkage between inflation and unemployment from 1952 to 2010 . The authors asserted that there was a direct link between inflation and unemployment in the country.

In conclusion, testing Philip's curve with historical data of unemployment and inflation has a sparked off debate in the recent times. It is observed that the results of the past studies have not reach a consensus which makes the literature to be inconclusive about this subject matter. Hence, the relevance of this study.

\section{Methodology and Estimation}

This study involves the use of secondary data from 1990 to 2018 . The study utilized 1990 as base year because inflation and unemployment became issues of concern in Nigeria after the adoption the Structural Adjustment Program. Meanwhile, inflation and unemployment data were sourced from the CBN Bulletin 


\section{Empirical Model}

In testing for the existence or otherwise of Philip's curve in this study requires econometric technique that involves a bi-variate analysis. This choice of methodology was motivated due to the fact only two variables namely inflation and unemployment are required for the examination of the existence or otherwise of the Philips curve in Nigeria. In the light of the above, this study limited the number of variables of interest to only inflation and unemployment, because addition of any variable could influence the outcome of the study which might contradict the theoretical foundation of this work. Therefore, this study follows the methodology put forward by Philps (1956) and Dritsaki and Dritsaki (2012) in which the model incorporate only inflation and unemployment in such a way that unemployment serves the dependent variable and inflation as independent variable. Thus, the model is specified as follows;

Unemployment $=\mathrm{f}($ Inflation $)$

$\mathrm{UEMR}=\mathrm{f}(\mathrm{Infl})$

If equation (2) is linearized, it leads to equation (3)

$\mathrm{UEMRt}=\delta_{0}+\delta_{1}$ Inflt $+\mathrm{Ut}$

If model (3) could be transformed to capture error correction model as in model (4)

$\Delta U E M R_{t}=\beta_{0}+\sum_{i=1}^{p} \beta_{1} \Delta U E M R_{t-1}+\sum_{i=0}^{p} \beta_{2} \Delta I n f_{t-1}+\Omega E C M_{t-1}+$ $\theta_{1} U E M R_{t-1}+\theta_{2} \operatorname{Infl}_{t-1}+\mu \mathrm{i}$

Where

UEMR is unemployment rate which measures the percentage of unemployed workers in the total labour fource in the country. Infl is Inflation rate and consumer price index is used to proxy it. $\mu_{i}=$ Stochastic or error term and $\mathrm{t}=1990-2018$. Meanwhile, the a priori expectations are as follows $\beta 2$, $\theta_{2}$ and $\Omega<0$

\section{Results}

Table 1: Descriptive Statistics of Annual Data Series (1990-2018)

\begin{tabular}{|l|l|l|}
\hline Descriptive Statistics & Infl & UEMR \\
\hline Mean & 18.48862 & 13.31759 \\
\hline Median & 12.22000 & 13.10000 \\
\hline Maximum & 72.84000 & 29.70000 \\
\hline Minimum & 5.380000 & 3.440000 \\
\hline Std. Deviation & 17.15360 & 8.433022 \\
\hline Skewness & 0.016217 & 0.349255 \\
\hline Kurtosis & 5.896723 & 1.999495 \\
\hline Jargue-Bera & 0.178726 & 1.799119 \\
\hline Probability & 0.000000 & 0.406749 \\
\hline
\end{tabular}




\begin{tabular}{|l|l|l|}
\hline Sum & 536.1700 & 386.2100 \\
\hline Sum. Sq. Deviation & 8238.891 & 1991.244 \\
\hline Observation & 28 & 28 \\
\hline
\end{tabular}

Source: Authors` Computation (2019)

It has been submitted that econometric analysis requires the normal distribution of data series as important factor because the asymptotic distribution of data is one the strategic assumptions upon which regression analysis is premised. As such, this study evaluates the descriptive statistics of the variables of interest with the presentation of the results in table one. Consequently, consumer price index which measures inflation rate in Nigeria during the period of 28 years possesses a minimum value of $5.380000 \%$ and maximum value of $72.84000 \%$ respectively. In the same vain, the variable has a mean value of $18.4 \%$ with standard deviation of $17.1 \%$. It shows that CPI data deviate from the both sides of mean by $17.1 \%$. The dispersion of the data is moderate because its mean value is greater than standard deviation. Also, skewedness of the data has value of 0.016217 and Kurtosis of 5.896723. This implies that the data is positively skewed without agreeing with the symmetrical distribution assumption because the value of Kurtosis is greater than 3.

Similarly, unemployment rate data covering the period of 28 years have a minimum and maximum values of $3.440000 \%$ and $29.70000 \%$ concurrently. It has mean value of $13.3 \%$ and standard deviation of $8.4 \%$. Though the data deviate from both sides of mean by $8.4 \%$, the dispersion is wide because the mean value of the variable is greater than its standard deviation. The data is positively skewed with Kurtosis value of 1.9. This implies that the data shows a partial agreement with the symmetrical distribution assumption due the fact the value of Kurtosis is close to 3 .

Table 2: Unit Root Test

\begin{tabular}{|l|l|l|l|l|l|}
\hline \multirow{2}{*}{ Variables } & \multicolumn{4}{|c|}{ ADF Test } & \\
\cline { 2 - 6 } & Level & Probability & $1^{\text {st }}$ Diff & Probability & Remark \\
\hline INF & $-2.976263^{* * *}$ & 0.1390 & -2.976263 & 0.0025 & $\mathrm{I}(1)$ \\
\hline UNEM & $-2.971853^{* * *}$ & 0.7070 & -2.976263 & 0.0019 & $\mathrm{I}(1)$ \\
\hline Variables & \multicolumn{7}{|c|}{ PP Test } & \\
\cline { 2 - 6 } & Level & Probability & $1^{\text {st }}$ Diff & Probability & \\
\hline INF & $-2.971853^{* * *}$ & 0.1910 & - & 0.0028 & $\mathrm{I}(1)$ \\
\hline UNEM & $-2.971853^{* * *}$ & 0.7660 & 2.976263 & & $\mathrm{I}(1)$ \\
\hline
\end{tabular}

Source: Authors` Computation (2019)

$* * * \% 5$ level 
It has been argued in the literature that time series data are always associated with the problem of the stationarity which could cause a spurious or nonsense regression if analysis is based on such data. In order to eliminate the emergence of spurious regression in this study, an attempt was made to investigate stationarity property of the data via the standard Augmented Dickey-Fuller (ADF) and Phillips-Perron (PP) tests. It is important to state that the estimated results presented in table 2 justified the fact that the data are not stationary in their native form. This shows that the data employed for this study possess a unit root. In another words, they are I(1) variables.

\section{Table 3: Engle Granger Cointegration Test}

\begin{tabular}{|l|l|l|l|l|l|}
\hline \multirow{2}{*}{ Variables } & \multicolumn{4}{|c|}{ ADF Test } & \\
\cline { 2 - 6 } & Level & Probability & $1^{\text {st }}$ Diff & Probability & Remark \\
\hline Residual & $-2.976263 * * *$ & 0.0361 & - & - & I(0) \\
\hline
\end{tabular}

\section{Source: Authors`Computation (2019)}

The variables of interest in this study are I(1) variables as indicated in the previous table. This means that these variables could deviate in the short run but have a possibility of a long run convergence. In order to examine the existence or otherwise of this convergence in the long run, this study employed residual based conitegration test advanced by Engle and Granger (1987). This technique is relevant because this study is a bivariate analysis. Consequently, the result of the unit root test on the residual of the regression of the bivariate model is $\mathrm{I}(0)$. This implies that the unemployment rate and inflation rate have a long run equilibrium.

\section{Table 4: VAR Lag Order Selection Criteria}

Endogenous variables: INF UMR

Exogenous variables: $\mathrm{C}$

Sample: 19902018

Included observations: 27

\begin{tabular}{llllll}
\hline \hline Lag & LogL & LR & FPE & AIC & SC \\
\hline \hline 0 & -205.9443 & NA & 16774.15 & 15.40328 & 15.49927 \\
1 & -174.3684 & $56.13486^{*}$ & $2179.200^{*}$ & $13.36062 *$ & $13.64859^{*}$ \\
2 & -171.3544 & 4.911707 & 2360.323 & 13.43366 & 13.91360 \\
\hline \hline
\end{tabular}

* indicates lag order selected by the criterion

LR: sequential modified LR test statistic (each test at 5\% level)

FPE: Final prediction error 
In determining the appropriate optimal lag length, conventional diagnostic tests such as Final prediction error, Schwarz information criterion, Schwarz information criterion, the Akaike Information Criterion were carried out in this study, with the results presented in table 4 . The results show that the optimal lag length is 1 as indicted by all information criteria.

Table 5: Parsimonious Short Run and Long Run Regression Estimates

\begin{tabular}{|l|l|l|l|l|l|l|l|}
\hline $\begin{array}{l}\text { Short } \\
\text { Run }\end{array}$ & $\begin{array}{l}\text { Coefficien } \\
\mathrm{t}\end{array}$ & T-Value & $\begin{array}{l}\text { Prob. } \\
\text { Value }\end{array}$ & Long Run & $\begin{array}{l}\text { coeffici } \\
\text { ent }\end{array}$ & T-Value & $\begin{array}{l}\text { Prob. } \\
\text { Value }\end{array}$ \\
\hline $\begin{array}{l}\text { DUEM(- } \\
1)\end{array}$ & 0.169382 & $\begin{array}{l}0.83975 \\
6\end{array}$ & 0.3859 & $\begin{array}{l}\text { UEMR(- } \\
1)\end{array}$ & $\begin{array}{l}0.8748 \\
19\end{array}$ & 9.783384 & 0.0000 \\
\hline DInfl & 0.021746 & $\begin{array}{l}0.38786 \\
4\end{array}$ & 0.7017 & Infl & $\begin{array}{l}- \\
0.0412 \\
93\end{array}$ & 0.958649 & 0.3469 \\
\hline $\begin{array}{l}\text { ECM } \\
\text { R- } \\
\text { Squared }\end{array}$ & -0.162437 & $\begin{array}{l}2.64958 \\
5\end{array}$ & 0.0026 & R-Squared & $\begin{array}{l}0.8406 \\
40\end{array}$ & & \\
\hline
\end{tabular}

\section{Dependent Variable: UEMR}

\section{Source: Authors`Computation (2019)}

The estimated results of both the short run and long run relationship between unemployment and inflation in Nigeria are presented in the table above. The coefficient of the error correction model follows the aprori expectation which is negative and significant. The implication of this is that the speed of adjustment for inflation and unemployment to return to the long run equilibrium state when there is a short run disequilibrium due to shock is $16 \%$ on annual basis. The lagged value of unemployment rate is positive in both the short run and the long run. This implies that unemployment in the previous year would lead to unemployment in the current year in the short run and the long run in Nigeria. However, the short run estimate shows that there is a positive relationship between unemployment and inflation in Nigeria, though not statistically significant. A unit change in unemployment leads to a rise in inflation by $0.02 \%$ in Nigeria in the short run. It is instructive to state that this finding contradicts the Philip's curve theory which states that a tradeoff exists between inflation and unemployment in an economy. This shows that the Nigerian economy is anti-Philip's curved in the short run. This submission is in tandem with the conclusions of Salisu, Chindo, Yahaya and Bello (2018) and Anthony, Anthony and Joan (2015) in related studies in Nigeria but contradicts the findings of Tejvan (2011) in a related study in the United States and the United Kingdom. 
Furthermore, the long run estimate shows an insignificant inverse relationship between inflation and unemployment in Nigeria. A unit change in unemployment leads to a reduction in inflation by $0.04 \%$ in the long run. This means that there is a trade-off exists between unemployment and inflation in Nigeria in the long run. Therefore, evidence to support the Philip's Curve theory exists in the long run in Nigeria. This finding is line with the submission of Aminu and Anono (2012) in a related study in Nigeria.

3.2 Diagnostic and Stability Tests

Table 6: Breusch-Godfrey Serial Correlation LM Test

\begin{tabular}{llll}
\hline F-statistic & 1.076164 & Prob. F(2,21) & 0.3590 \\
Obs*R-squared & 2.510022 & Prob. Chi-Square(2) & 0.2851
\end{tabular}

Source: Authors`Computation (2019)

Table 7: Heteroskedasticity Test: Breusch-Pagan-Godfrey

\begin{tabular}{lrll}
\hline \hline F-statistic & 2.486566 & Prob. F(3,23) & 0.0860 \\
Obs*R-squared & 6.612405 & Prob. Chi-Square(3) 0.0853 \\
Scaled explained SS 6.200522 & Prob. Chi-Square(3) 0.1023 \\
\hline \hline
\end{tabular}

Source: Authors` Computation (2019)

Figure 1: Histogram and Normality Test

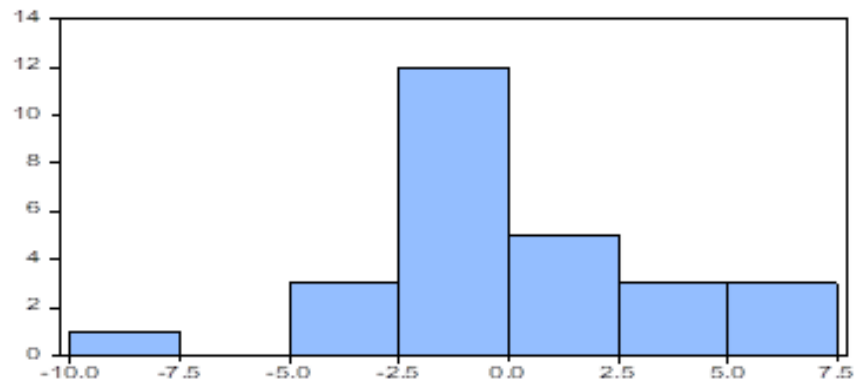

\begin{tabular}{|c|c|}
\hline \multicolumn{2}{|c|}{$\begin{array}{l}\text { Series: Residuals } \\
\text { Sample } 19922018 \\
\text { Observations } 27\end{array}$} \\
\hline Maan & $-6.58 \mathrm{e}-17$ \\
\hline $\begin{array}{l}\text { Median } \\
\text { Maximum } \\
\text { Mnimum }\end{array}$ & $\begin{array}{r}-0.607270 \\
7.125749 \\
-8.477372\end{array}$ \\
\hline $\begin{array}{l}\text { Std. Dev. } \\
\text { Skewness } \\
\text { Kurtosis }\end{array}$ & $\begin{array}{l}3.335793 \\
0.160228 \\
3.584465\end{array}$ \\
\hline $\begin{array}{l}\text { Jarque-Bera } \\
\text { Probability }\end{array}$ & $\begin{array}{l}0.499829 \\
0.778867\end{array}$ \\
\hline
\end{tabular}




\section{Figure 2: Plot of cumulative sum of recursive residuals}

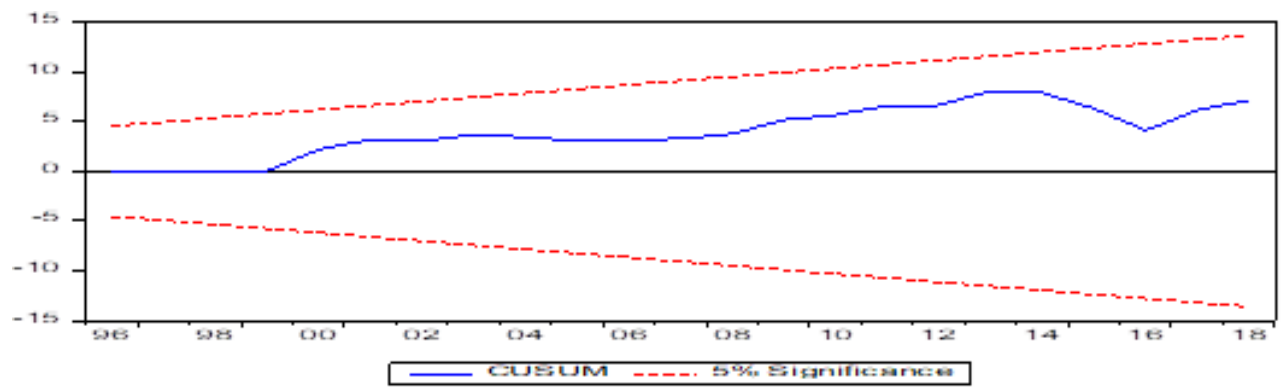

In order to determine how appropriate the adopted parsimonious model in this study is, further effort was made to examine various diagnostic tests and stability tests in the above tables and figures. It could be inferred from the above that the model is free from serial correlation and heteroskedasticity in one hand and the estimated parameters are stable over the period of 1990 to 2018

\section{Conclusion}

This study examined the relationship between unemployment and inflation via the application of Engle and Granger and Error Correction Model approach, with a view to testing the existence or otherwise of Philip`s curve theory in Nigeria between 1990 and 2018. The following are the major findings that originated from this work; the speed of adjustment for inflation and unemployment to return to the long run equilibrium state when there is a short run disequilibrium due to shock is $16 \%$ on annual basis. The lagged value of unemployment rate is positive in both the short run and the long run. In the same vein, the short run estimate shows a positive relationship between unemployment and inflation in Nigeria, though not statistically significant. This implies that the Nigerian economy is anti-Philip's curved in the short run. However, the long run relationship between the variables of interest shows the evidence to support the existence of Philip's Curve theory in Nigeria. Therefore, this study makes these policy recommendations to the policy makers in Nigeria based on its findings: since both inflation and unemployment are macroeconomic problems that could hinder the achievement of sustainable development goal 8- inclusive and sustainable economic growth, full and productive employment and decent work for all, the policy makers in Nigeria should embark on various stabilization policies to address continuous rising in inflation rate and create jobs to address unemployment menace in the country. 


\section{References:}

1. Alfred, A. \& Ian. (2011). Empirical Evidence on Inflation and Unemployment in the long run. University of Otago Economics Discussion Paper.

2. Aminu, U. \& Anono, A.Z. (2012). An empirical Analysis of The Relationship between Unemployment and Inflation in Nigeria from 1977-2009, Business Journal, Economics and Review, 1(12): 4261.

3. Anthony, O. Anthony, O.I. \& Joan, C. O. (2015). Inflation and Unemployment Nexus in Nigeria: Another Test of the Phillip's Curve. Asian Economic and Financial Review, 5(5):766-778

4. Carlos, J.G., (2010). Is the Phillips curve useful for monetary policy in Nigeria?Research Department Central Bank of Abuja. Occassional Paper No. 38.

5. Central Bank of Nigeria. (2018). Statistical bulletin. Abuja: Central Bank of Nigeria

6. Dickey, D. A. \& Fuller, W. A. (1979). Distribution of the Estimators for Autoregressive Time Series with a Unit Root. Journal of the American Statistical Association, 74: 427-431.

7. Dritsaki, C., \& Dritsaki, M. (2012). Inflation, Unemployment and the NAIRU in Greece. Procedia Economics and Finance, 1(12), 118-127

8. Engle, R. F. \& Granger, C.W.J. (1987). Co-integration and Error Correction representation, Estimation and Testing. Econometricia, $55: 251-276$

9. Fagge, A. (2011). The Socio-Economic Effects of Unemployment in Nigeria. Economic Discussion Paper.

10. Ola- David, O. and Oluwatobi, S. (2012). Output and unemployment relationship: How applicable Is the Okun's law to Nigeria? Available from SSRN: http://ssrn.com/abstract=2512898 or http://dx.doi.org/10.2139/ssrn.2512898.

11. Olubaduwe (2009) Inflation, unemployment and the Philips curve in sub- Sahara Africa. Journal of macroeconomic review. 57 (2009) 233-243 Phillips, P. C. and Perron, P. 1988. Testing for a unit root in time series regression. Biometrika,75:335-346.

12. Phillips, A. W. (1958). The Relationship between Unemployment and the Rate of Change of Money Wages in the United Kingdom 1861- 1957, Economica, 25(100): 283-299

13. Salisu, B. M., Chindo, S., Yahaya, Y. \& Bello, I. U. (2018). Inflation and Unemployment in Nigeria: Does the Philips Curve Hold? An ARDL Bound Approach. International Journal of Education and Social Science Research, 1(2); 136-148 
14. Tejvan Pettinger(2011), "Trade-off Between Unemployment and Inflation". 